\title{
Use of Additives to Enhance the Properties of Cottonseed Protein as Wood Adhesives
}

\author{
H. N. Cheng*, Catrina Ford, Michael K. Dowd, Zhongqi He \\ Southern Regional Research Center, USDA Agricultural Research Service, 1100 Robert E. Lee \\ Blvd., New Orleans, LA 70124, USA
}

\begin{abstract}
Soy protein is currently being used commercially as a "green" wood adhesive. Previous work in this laboratory has shown that cottonseed protein isolate, tested on maple wood veneer, produced higher adhesive strength and hot water resistance relative to soy protein. In the present study, cottonseed protein and soy protein isolates were tested on different wood types, and cottonseed protein again showed better performance relative to soy protein. Furthermore, the effects of several protein modifiers were evaluated, including amino acids, fatty acids, and other organic molecules with cationic or anionic charges. Aspartic acid, glutamic acid, acetic acid, butyric acid, and adipic acid gave improved performance when included with cottonseed protein isolate whereas no significant effect was observed on soy protein isolate. Both dry adhesive strength and hot water resistance were tested. The enhanced performance observed with these additives provides an additional incentive for the use of cottonseed protein in this application.
\end{abstract}

Keywords: Cottonseed protein; soy protein; adhesion; wood veneer; protein modifiers

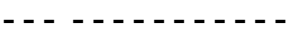

* Corresponding author: Tel.: 1-504-286-4450

Email address: hn.cheng@ars.usda.gov 


\section{Introduction}

The global wood adhesives and binders market is valued at $\$ 13.15$ billion with a volume of 16,200 kilo tons in 2013 [1]. Most of the adhesives are based on urea-formaldehyde, melamineurea-formaldehyde and phenol-formaldehyde resins. In order to decrease the usage of formaldehyde and petroleum-derived raw materials, there has been a partial shift in the past 15 years towards more eco-friendly bio-based wood adhesives, e.g., those based on soy and cellulose [2-5]. In particular, soy protein seems to be increasingly accepted in wood adhesive formulations, with several products having been commercialized [6-8].

Cottonseed protein isolate can be prepared from defatted cottonseed flour via alkaline extraction followed by acidic precipitation $[9,10]$. In previous work [11], we showed cottonseed protein isolate to exhibit superior adhesive strength and improved hot water resistance relative to soy protein isolate when used to bind maple wood veneer. In a follow-up work [12], we used sequential fractionation of cottonseed meal and found the adhesive properties of water and phosphate-buffer washed solid fractions to be almost as good as cottonseed protein isolate. These fractions were later tested on maple and poplar veneers with similar results [13]. Another recent publication showed that the addition of tung oil to water-washed cottonseed meal and cottonseed protein isolate improved adhesive strength and water resistance on maple veneer [14].

Adhesion of soy protein on several types of wood has been reported in the literature $[15,16]$. In the present study, we looked at adhesion of both cottonseed protein and soy protein isolates on different veneers, including maple, walnut, pine, and cherry. Modification of protein formulations with alkali, guanidine hydrochloride, sodium dodecyl sulfonate, and urea has also been shown to affect the adhesive properties of soy protein [11,15,17-19] and cottonseed protein [11]. Other modifiers previously studied with soy proteins included various plasticizers [20], ethylene glycol and its polymers [21], cationic polyacrylamide [22], clay [23], calcium carbonate [24], and combinations of acid, base, and salt [25]. In this work we examined several new protein modifiers, and some were found to exhibit improved adhesive strength when incorporated into cottonseed protein.

\section{Experimental}




\subsection{Materials}

Cottonseed protein isolate was prepared from defatted glandless cottonseed meal using the single-step alkaline extraction acid precipitation procedure reported in the literature $[9,10]$. Basically, $50 \mathrm{~g}$ of cottonseed meal was dispersed with moderate stirring into $750 \mathrm{~mL}$ of $0.027 \mathrm{~N}$ sodium hydroxide solution for 30 minutes. The slurry was partitioned into separate centrifuge bottles, and the solids were pelleted by centrifugation for 10 minutes at $10,000 \mathrm{~g}$. The $\mathrm{pH}$ of the combined supernatants was adjusted to 5.0 with $1 \mathrm{~N}$ hydrochloric acid, which precipitated the protein isolate. The protein was recovered by centrifugation, washed with water, centrifuged again, and then freeze-dried. The nitrogen content of this material was $16.0 \%$.

When $3 \mathrm{~g}$ of the cottonseed protein product was dispersed in $25 \mathrm{~g}$ water, the slurry $\mathrm{pH}$ was 5.2. Soy protein isolate (Pro-Fam ${ }^{\circledR} 781$ ) was provided by Archer Daniels Midland Company (Decatur, Illinois, USA). The nitrogen content was $14.2 \%$. When $3 \mathrm{~g}$ of this protein was dispersed in $25 \mathrm{~g}$ water, the $\mathrm{pH}$ was 7.3. Maple, walnut, pine, and cherry wood veneer were acquired from Oakwood Veneer Company (Troy, Michigan, USA). Other reagents were purchased from Sigma Aldrich (Milwaukee, Wisconsin, USA) and used without further purification.

\subsection{Preparation of Protein Adhesives and Bonded Wood Samples}

The formulation of adhesives was adapted from those reported in the literature [15,26-28]. Adhesive preparations comprised $3 \mathrm{~g}$ protein and $25 \mathrm{~mL}$ distilled water, stirred for $2 \mathrm{~h}$ at room temperature. For formulations containing modifiers, the protein $(3 \mathrm{~g})$ and modifier (between 30 - $1500 \mathrm{mM}$ final concentration) was suspended in $25 \mathrm{~g}$ distilled water and stirred for $1 \mathrm{~h} \mathrm{[26-27].}$ The $\mathrm{pH}$ for each modifier preparation was adjusted with sodium hydroxide or hydrochloric acid to the same value as that of the protein by itself.

The adhesive preparations were applied to pieces of wood veneer [6,28]. Wood veneer with a thickness of $0.6 \mathrm{~mm}$ was cut into strips $0.5 \mathrm{in}$. wide by $3.5 \mathrm{in}$. long with the wood grain parallel to the long dimension. The adhesive preparation was applied to one side and one end of the wood veneer strip, covering an area of 0.5 in. $x 1$ in. After 10 minutes of air drying, a second layer of adhesive was applied over the first layer. Two wood veneer strips were then stacked 
with the adhesive sections overlapping to generate a bonded area of 0.5 in $\mathrm{x} 1 \mathrm{in}$. The two strips were then hot-pressed for $20 \mathrm{~min}$ at $80^{\circ} \mathrm{C}$ and $2000 \mathrm{psi}$. Ten bonded composites were prepared and tested for each adhesive preparation.

\subsection{Measurement of adhesive strength}

Adhesive strength was measured with a Zwick stress tester (Zwick GmbH \& Co., Ulm, Germany). The crosshead speed was $1 \mathrm{~mm} / \mathrm{min}$. Bond strength was reported as maximum shear strength at breakage (in MPa) and as maximum elongation at break (\%). Ten bonded strips were tested for each formulation studied, and the mean and the standard deviations were calculated. Analysis of variance was used to compare differences in adhesive performance (SAS Institute, Cary, North Carolina, USA).

\subsection{Water resistance of the wood composites}

The procedure was similar to that used before [11] as adapted from previous work [29-30] and ASTM D1151-00 [31]. For this test, the wood veneers were cut into strips with the dimensions of 1.0 in $\times 3.5$ in. Each adhesive preparation was applied twice to the $1 \mathrm{in}$. end of the wood side of each veneer strip. Pairs of maple strips were overlapped and hot-pressed for 10 $\min$ at $100^{\circ} \mathrm{C}$ for $10 \mathrm{~min}$ and $2000 \mathrm{psi}$.

After cooling, the bonded wood strips were heated in water for $4 \mathrm{~h}$ at $63 \pm 3{ }^{\circ} \mathrm{C}$ and dried at room temperature for $24 \mathrm{~h}$. The bonded pairs were heated again in water for $4 \mathrm{~h}$ at $63 \pm 3{ }^{\circ} \mathrm{C}$ and then cooled with tap water. They were then air-dried for $24 \mathrm{~h}$ and evaluated on the Zwick stress tester for maximum tensile strength and maximum elongation at break. Ten bonded composites were tested for each adhesive preparation.

\section{Results and Discussion}

\section{1 Different wood types}


In an earlier work we showed that cottonseed protein isolate gave better performance on maple veneer than soy protein isolate [11]. Later, we studied the adhesive behavior on poplar veneers [13]. It would be useful to see if the favorable performance of cottonseed protein can be observed on pine, walnut and cherry wood veneers. It appears that under the testing conditions, the results are similar irrespective of wood type (Table 1). For all these wood veneer types, cottonseed protein shows better adhesive strength than soy protein.

The hot water resistance data for these proteins and wood veneers are shown in Table 2. Cottonseed protein isolate gives greater adhesive strength than soy protein after hot water treatment for all wood types. Some wood types (e.g., walnut) appeared to give slightly better adhesive strength after hot water treatment than the other tested wood types. In the literature different adhesion values on soy proteins for several wood types were reported, and the differences were attributed to roughness or smoothness of the wood surfaces $[15,16]$.

\subsection{Modifiers for Proteins}

Several modifiers were tested to see if they affect the adhesive properties of both types of protein isolate. In view of the current trend toward the use of "green" and environmentally friendly agri-based materials, amino acids and fatty acids were tried initially. Several amino acids were tested including charge neutral amino acids (glycine, leucine, tyrosine), potentially cationically charged amino acids (arginine, histidine and lysine), potentially anionically charged amino acids (aspartic and glutamic acids); these included amino acids having an aliphatic (leucine) and aromatic side chain (tyrosine). Three fatty acids were included: oleic acid, palmitic acid, and stearic acid. In order to further evaluate the effect of cationic and anionic compounds, choline chloride, acetic acid, butyric acid, and adipic acid were also included. For consistency, the formula names of the modifiers are given even though at the $\mathrm{pH}$ involved the amino acids are mostly in the zwitterionic form and the acids are mostly in the form of acid salts.

In an initial experiment, each modifier was added at $0.5 \mathrm{M}$ concentration, and the $\mathrm{pH}$ was adjusted to be the same as the protein by itself using $\mathrm{NaOH}$ or $\mathrm{HCl}$. From the data for the cottonseed protein with modifiers (Table 3), it appeared that the amino acids without ionic charges (glycine, tyrosine, leucine), amino acids with ionizable cationic charges (histidine, lysine) and the long-chain fatty acids (stearic, palmitic, and oleic) showed no benefit to either 
tensile strength or elongation at break. However, smaller molecules that carry anionic charges (aspartic acid, glutamic acid, acetic acid, adipic acid and butyric acid) showed enhanced adhesive strength relative to cottonseed protein control. Modifiers that carry non-ionizable cationic charges (arginine and choline chloride) also appeared to have a positive effect on the tensile strength of cottonseed protein, but the elongation at break data were less certain.

Different results were obtained for soy protein isolate (Table 3). Aspartic acid, glutamic acid, butyric acid, acetic acid, and adipic acid, as well as arginine and choline chloride produced similar tensile strength and elongation at break values as soy protein isolate itself (tensile strength $1.50 \mathrm{MPa}$ and elongation at break 1.2\%). For both soy protein and cottonseed protein, glycine (as the structurally simplest amino acid) had no apparent effect on the adhesive strength of the protein formulation.

In order to confirm these results and to understand the observation better, we carried out dosage-dependent studies on selected modifiers: aspartic acid, glutamic acid, arginine, choline chloride, butyric acid, and adipic acid. (Acetic acid was skipped because of its structural similarity to butyric and adipic acid.) The results for cottonseed protein are shown in Table 4. For the cottonseed protein isolate with these tested modifiers, a $0.1-0.5 \mathrm{M}$ concentration range gave the strongest enhancement, with the results decreasing at lower and higher doses. The modifiers with the most enhancements on cottonseed protein were aspartic acid, adipic acid, glutamic acid, and butyric acid. The enhancement effect of arginine and choline chloride on cottonseed protein was significant but weaker than the enhancement achieved for the acids. For soy protein isolate, many of the additives had values of tensile strength and elongation at break values near those of the soy protein isolate used alone.

In view of the adhesive strength results given in Tables 4 and 5, hot water resistance tests were carried out on cottonseed and soy protein isolates with aspartic, glutamic, butyric, adipic, and acetic acids, and with arginine. Each of the additives was added at $0.5 \mathrm{M}$ concentration to the protein, and the $\mathrm{pH}$ was adjusted to be the same as the protein without additive. The results are given in Table 6. The good hot water resistance feature of cottonseed protein was retained in the presence of these six additives. In contrast, the hot water resistance of soy protein isolate seemed to be negatively impacted by these additives, with arginine showing the biggest impact with all the adhesive joints failing during the heat soak treatment. 
The enhancement of aspartic acid, glutamic acid, butyric acid, adipic acid, and acetic acid on the adhesive strength of cottonseed protein is of interest. These are all small molecules that carry carboxylate ions. The performance of a protein in an adhesive formulation likely depends on the reaction of protein with the wood surface and on the formation of crosslinked networks among the denatured protein molecules during the heat bonding process. Cottonseed protein contains more arginine (11-12\%) than does soy protein (7-8\%). As arginine carries a net cationic charge at most $\mathrm{pH}$ values (up to 12.0), the additive carboxylate anions may interact with proteinaceous arginine (and other cationic moieties) to form anion-protein bridge interactions. Such interactions are believed to facilitate protein denaturation and destabilization, although the mechanisms responsible are debated [32,33]. In addition, arginine is known to decrease heatinduced protein aggregation [35-36], making the protein more easily denatured at temperatures above $80^{\circ} \mathrm{C}$ [37]. The addition of carboxylate ions with additional bulk may facilitate this process. Moreover, the additives may perhaps enhance the mobility of the protein chains during the bonding process. For example, octanoic acid has been found to be a plasticizer for proteins [34], and it is likely that the additives may have some plasticizing effect in the protein formulations. Finally, glutamic and aspartic acid are among the amino acids that are capable of thermal polymerization [38-39], which might also contribute to the observed strength enhancement. Further investigation into the behavior of cottonseed protein in the presence of different additives is ongoing.

\section{Conclusions}

In this work a number of amino acids, fatty acids, and small molecules with anionic or cationic charges were studied as modifiers for cottonseed and soy protein isolate-based wood adhesion. For cottonseed protein based preparations, compounds having an anionic charge in the formulations, e.g., aspartic acid, glutamic acid, acetic acid, butyric acid, and adipic acid exhibited the greatest effect. Yet, these same compounds give no significant improvement in the adhesive strength of soy proteins. Furthermore, these modifiers had no negative impact on the hot water resistance of the cottonseed protein wood adhesive, but decreased the hot water resistance of soy protein based formulations. In view of these results, the combination of 
cottonseed protein and one of these additives may be beneficial in the future product development of protein wood adhesives.

\section{Acknowledgments}

We thank Scott Pelitire for helping to prepare cottonseed protein isolate and Dr. K. Thomas Klasson for useful discussions. Mention of trade names or commercial products in this publication is solely for the purpose of providing specific information and does not imply recommendation or endorsement by the U.S. Department of Agriculture. USDA is an equal opportunity provider and employer

\section{References}

[1] Transparency Market Research, Wood adhesives and binders market - Global industry analysis, size, share, growth, trends and forecast, 2014 - 2020; 2014. http:/www.transparencymarketresearch.com/

[2] Pizzi A. Recent developments in eco-efficient bio-based adhesives for wood bonding: opportunities and issues. J Adhes Sci Technol 2006; 20(8): 829-846.

[3] Kumar R, Choudhary V, Mishra S, Varma I, Mattiason B. Adhesives and plastics based on soy protein products. Ind Crop Prod 2002; 16:155-172.

[4] Wang D, Sun XS, Yang G, Wang Y. Improved water resistance of soy protein adhesive at isoelectric point. Trans ASABE 2009; 52:173-177.

[5] Frihart CR, Birkeland MJ. Soy properties and soy wood adhesives. Am Chem Soc Symp Series 2014; 1178: 167-192. DOI: 10.1021/bk-2014-1178.ch008

[6] Li K., Peshkova S, Geng X. Investigation of soy protein-Kymene adhesive system for wood composites. J Am Oil Chem Soc 2004; 81:487-491.

[7] Allen AJ, Marcinko JJ, Wagler TA, Sosnowick AJ. Investigations of the molecular interactions of soy-based adhesives. Forest Prod J 2010; 60(6): 534-540.

[8] Orr L. Wood adhesives - A market opportunity study. Omni Tech International, Ltd., Midland, Michigan; 2007. 
http://www.soynewuses.org/downloads/reports/final_WoodAdhesivesMarketOpportunity.p $\underline{\mathrm{df}}$

[9] Berardi LC, Martinez WH, Fernandez CJ. Cottonseed protein isolates: two step extraction procedure. Food Tech 1969; 23:75-82.

[10] Martinez WH, Berardi LC, Goldblatt LA. Cottonseed protein products-composition and functionality. J Agric Food Chem 1970; 18: 961-968.

[11] Cheng HN, Dowd MK, He Z. Investigation of modified cottonseed protein adhesives for wood composites. Ind Crops Prod 2013; 46: 399-403.

[12] He Z, Cheng HN, Chapital DC, Dowd MK. Sequential fractionation of cottonseed meal to improve its wood adhesive properties. J Am Oil Chem Soc 2014; 91: 151-158.

[13] He Z, Chapital DC, Cheng HN, Dowd MK. Comparison of adhesive properties of waterand phosphate-buffer-washed cottonseed meals with cottonseed protein isolates on bonding maple and poplar veneers. Int J Adhes Adhes 2014; 50, 102-106.

[14] He Z, Chapital DC, Cheng HN, Klasson KT, Olanya O.M., Uknalis, J. Application of tung oil to improve adhesion strength and water resistance of cottonseed meal and protein adhesives on maple veneer. Ind Crops Prod 2014; 61: 398-402.

[15] Sun S, Bian K. Shear strength and water resistance of modified soy protein adhesives. J Am Oil Chem Soc 1999; 76: 977-980.

[16] Kalapathy U, Hettiarachchy NS, Myers D, Hanna MA. Modification of soy proteins and their adhesive properties on wood. J Am Oil Chem Soc 1995; 72: 507-510.

[17] Hettiarachchy NS, Kalapathy U, Myers DJ. Alkali-modified soy protein with improved adhesive and hydrophobic properties. J Am Oil Chem Soc 1995; 72:1461-1464.

[18] Huang W, Sun X. Adhesive properties of soy protein modified by urea and guanidine hydrochloride. J Am Oil Chem Soc 2000; 77:101-104.

[19] Huang W, Sun X. Adhesive properties of soy protein modified by sodium dodecyl sulfate and sodium dodecylbenzene sulfonate. J Am Oil Chem Soc 2000; 77:705-708.

[20] Mo X, Sun X. Plasticization of soy protein polymer by polyol-based plasticizers. J. Am. Oil Chem Soc 2002; 79: 197-202.

[21] Chen M, Chen Y, Zhou X, Lu B, He M, Sun S, Ling X. Improving water resistance of soyprotein wood adhesive by using hydrophilic additives. BioResources 1015; 10: 41-54. 
[22] Xu H, Luo J, Gao Q, Zhang S, Li J. Improved water resistance of soybean meal-based adhesives with SDS and PAM. BioResources 2014; 9: 4667-4678.

[23] Zhang Y, Zhu W, Lu Y, Gao Z, Gu J. Water-resistant soybean adhesive for wood binder employing combinations of caustic degradation, nano-modification, and chemical crosslinking. BioResouces 2013; 8: 1283-1291.

[24] Liu D, Chen H, Chang PR, Wu Q, Li K, Guan L. Biomimetic soy protein nanocomposites with calcium carbonate crystalline arrays for use as wood adhesive. Bioresource Technol 2010; 101: 6235-6241.

[25] Lin Q, Chen N, Bian L, Fan M. Development and mechanism characterization of high performance soy-based bio-adhesives. Int J Adhes Adhes 2012; 34: 11-16.

[26] Zhong Z, Sun XS, Fang X, Ratto JA. Adhesive strength of guanidine hydrochloridemodified protein for fiberboard application. Int J Adhes Adhes 2002; 22: 267-272.

[27] Sun XS, Wang D, Zhong Z. Adhesion performance of modified soy protein adhesive. DOD report, 2002. http://dodreports.com/pdf/ada414303.pdf

[28] Liu Y, Li K. Chemical modification of soy protein for wood adhesives. Macromol Rapid Comm 2002; 23: 739-742.

[29] Liu Y, Li K. Development and characterization of adhesives from soy protein for bonding wood. Int J Adhes Adhes 2007; 27: 59-67.

[30] Zhong Z, Sun XS, Wang D. Isoelectric $\mathrm{pH}$ of polyamide-epichlorohydrin modified soy protein improved water resistance and adhesion properties. J Appl Polym Sci 2007; 130: 2261-2270.

[31] ASTM 2013. Standard practice for effect of moisture and temperature on adhesive bonds (D1151-00). American Society of Testing and Materials, Philadelphia, PA, pp. 73-75.

[32] Li J, Bian H, We X, Cheng H, Yuan K, Zheng J. Probing ion/molecule interactions in aqueous solutions with vibrational energy transfer. J Phys Chem B 2012; 116: 1228412294.

[33] WaldronTT, Modestou MA, Murphy KP. Anion binding to a protein-protein complex lacks dependence on net charge. Protein Sci 2003; 12(4): 871-874.

[34] diGioia L, Guilber S. Corn protein-based thermoplastic resins: Effect of some polar and amphiphilic plasticizers. J Agric Food Chem 1999; 47: 1254-1261. 
[35] Lyutova EM, Kasakov AS, Gurvits BY. Effects of arginine on kinetics of protein aggregation studied by dynamic laser light scattering and turbidimetry techniques. Biotechnol Prog 2007; 23(6): 1411-1416.

[36] Tomita S, Hamada H, Nagasaki Y, Shiraki K. Synergistic effect of polyethylene glycol with arginine on the prevention of heat-induced aggregation of lysozyme. J. Phys.: Conf. Ser. 2008; 106: 012022. Doi:10.1088/1743-6596/106/1/012022.

[37] Han HJ. Innovations in Food Packaging. Elsevier Academic Press, San Diego, 2005, p. 289.

[38] Harada K, Fox SW. The thermal copolymerization of aspartic acid and glutamic acid. Archiv Biochem Biophys 1960; 86: 274-280.

[39] Fox SW. Self-ordered polymers and propagative cell-like systems. Naturwissenschaften 1969; 56: 1-9. 
Table 1. Adhesive properties of cottonseed protein (CSP) and soy protein (SP) isolates on different wood veneers*

\begin{tabular}{llll}
\hline Protein & Wood & $\begin{array}{c}\text { Tensile strength } \\
(\mathrm{MPa})\end{array}$ & $\begin{array}{c}\text { Elongation at } \text { break }^{* *} \\
(\%)\end{array}$ \\
\hline CSP & Pine & $2.40 \pm 0.18^{\mathrm{a}, \mathrm{b}}$ & $2.0 \pm 0.1^{\mathrm{b}, \mathrm{c}}$ \\
& Walnut & $2.62 \pm 0.25^{\mathrm{a}}$ & $2.1 \pm 0.1^{\mathrm{a}, \mathrm{b}}$ \\
& Cherry & $2.34 \pm 0.12^{\mathrm{b}}$ & $2.1 \pm 0.1^{\mathrm{a}}$ \\
& Maple & $2.37 \pm 0.17^{\mathrm{a}, \mathrm{b}}$ & $2.0 \pm 0.1^{\mathrm{b}, \mathrm{c}}$ \\
& & & \\
SP & Pine & $1.82 \pm 0.28^{\mathrm{c}}$ & $1.6 \pm 0.2^{\mathrm{d}}$ \\
& Walnut & $1.78 \pm 0.14^{\mathrm{c}}$ & $1.5 \pm 0.1^{\mathrm{d}}$ \\
& Cherry & $1.91 \pm 0.10^{\mathrm{c}}$ & $1.8 \pm 0.1^{\mathrm{c}}$ \\
& Maple & $1.71 \pm 0.11^{\mathrm{c}}$ & $1.5 \pm 0.1^{\mathrm{d}}$ \\
\hline
\end{tabular}

\footnotetext{
${ }^{*}$ Testing done on bonded wood composite strips 0.5 in. x 3.5 in. with a glued 0.5 in. x 1 in. overlap between two strips.

${ }^{* *} \mathrm{n}$ (number of wood composites) $=10$ for each treatment. Data in each column with the same superscript letter indicates that the treatments are not significantly different at $p=0.05$.
}

Table 2. Hot water resistance testing of cottonseed protein (CSP) and soy protein (SP) isolates on different wood veneers ${ }^{*}$

\begin{tabular}{llcll}
\hline Protein & Wood & \# obs. $^{* *}$ & $\begin{array}{c}\text { Tensile strength } \\
(\mathrm{MPa})\end{array}$ & $\begin{array}{c}\text { Elongation at break } \\
(\%)\end{array}$ \\
\hline CSP & Pine & 10 & $2.43 \pm 0.33^{\mathrm{b}, \mathrm{c}}$ & $3.0 \pm 0.3^{\mathrm{b}}$ \\
& Walnut & 10 & $2.74 \pm 0.27^{\mathrm{a}, \mathrm{b}}$ & $3.4 \pm 0.3^{\mathrm{b}}$ \\
& Cherry & 10 & $2.28 \pm 0.10^{\mathrm{c}}$ & $3.1 \pm 0.1^{\mathrm{b}}$ \\
& Maple & 10 & $3.04 \pm 0.30^{\mathrm{a}}$ & $4.9 \pm 0.5^{\mathrm{a}}$ \\
SP & & & & \\
& Pine & 10 & $0.57 \pm 0.30^{\mathrm{e}}$ & $1.0 \pm 0.3^{\mathrm{d}}$ \\
& Walnut & 8 & $1.01 \pm 0.24^{\mathrm{d}}$ & $1.6 \pm 0.3^{\mathrm{c}}$ \\
& Cherry & 7 & $0.13 \pm 0.06^{\mathrm{f}}$ & $0.5 \pm 0.1^{\mathrm{e}}$ \\
& Maple & 9 & $0.31 \pm 0.19^{\mathrm{e}, \mathrm{f}}$ & $2.0 \pm 0.5^{\mathrm{c}}$ \\
\hline
\end{tabular}

\footnotetext{
${ }^{*}$ Testing conducted on bonded wood composite strips 1.0 in. $\times 3.5$ in. with a glued 1.0 in. $x 1.0$ in. overlap between two strips.

${ }^{* *}$ Number of wood composites that remained attached after hot water treatment. (Total number of wood composites $=10$.) Only composites where wood strips stayed attached were tested for tensile strength and elongation at break.

${ }^{* * *}$ Data in each column with the same superscript letter indicates that the treatments are not significantly different at $\mathrm{p}=0.05$.
} 
Table 3. Tensile strength and elongation at break for cottonseed protein (CSP) and soy protein (SP) isolates with different additives at $0.5 \mathrm{M}$ concentration ${ }^{*}$

\begin{tabular}{|c|c|c|c|}
\hline Protein & Additive & $\begin{array}{c}\text { Tensile strength }^{* *} \\
(\mathrm{MPa})\end{array}$ & $\begin{array}{c}\text { Elongation at break } \\
(\%)\end{array}$ \\
\hline $\mathrm{CSP}$ & None & $2.51 \pm 0.21^{\mathrm{f}, \mathrm{g}}$ & $1.9 \pm 0.2^{\mathrm{c}, \mathrm{d}}$ \\
\hline CSP & Glycine & $2.54 \pm 0.18^{\mathrm{f}, \mathrm{g}}$ & $1.9 \pm 0.2^{\mathrm{d}, \mathrm{e}}$ \\
\hline CSP & Histidine & $2.62 \pm 0.15^{\mathrm{e}, \mathrm{f}, \mathrm{g}}$ & $1.9 \pm 0.1^{\mathrm{d}, \mathrm{e}}$ \\
\hline CSP & Aspartic acid & $3.45 \pm 0.30^{\mathrm{a}, \mathrm{b}}$ & $2.6 \pm 0.2^{\mathrm{a}}$ \\
\hline CSP & Glutamic acid & $3.17 \pm 0.15^{\mathrm{c}, \mathrm{d}}$ & $2.3 \pm 0.1^{\mathrm{b}}$ \\
\hline CSP & Arginine & $2.95 \pm 0.37^{\mathrm{d}, \mathrm{e}}$ & $2.1 \pm 0.2^{\mathrm{c}}$ \\
\hline CSP & Lysine & $1.43 \pm 0.46^{\mathrm{i}}$ & $1.2 \pm 0.3^{\mathrm{g}}$ \\
\hline CSP & Tyrosine & $1.64 \pm 0.10^{\mathrm{i}}$ & $1.3 \pm 0.1^{\mathrm{g}}$ \\
\hline CSP & Leucine & $1.59 \pm 0.19^{\mathrm{i}}$ & $1.2 \pm 0.1^{\mathrm{g}}$ \\
\hline CSP & Stearic acid & $2.08 \pm 0.25^{\mathrm{h}}$ & $1.6 \pm 0.2^{\mathrm{f}}$ \\
\hline CSP & Palmitic acid & $2.30 \pm 0.21^{\mathrm{g}, \mathrm{h}}$ & $1.7 \pm 0.1^{\mathrm{e}, \mathrm{f}}$ \\
\hline CSP & Oleic acid & $1.61 \pm 0.15^{\mathrm{i}}$ & $1.3 \pm 0.1^{\mathrm{g}}$ \\
\hline CSP & Choline chloride & $2.76 \pm 0.21^{\mathrm{d}, \mathrm{e}, \mathrm{f}}$ & $1.9 \pm 0.1^{\mathrm{c}, \mathrm{d}}$ \\
\hline CSP & Acetic acid & $3.31 \pm 0.28^{b}$ & $2.3 \pm 0.2^{\mathrm{b}}$ \\
\hline CSP & Butyric acid & $2.90 \pm 0.17^{\mathrm{d}, \mathrm{e}}$ & $2.1 \pm 0.1^{\mathrm{c}}$ \\
\hline CSP & Adipic acid & $3.61 \pm 0.23^{\mathrm{a}}$ & $2.5 \pm 0.2^{\mathrm{a}, \mathrm{b}}$ \\
\hline SP & None & $1.50 \pm 0.15^{\mathrm{a}, \mathrm{b}}$ & $1.2 \pm 0.1^{\mathrm{a}, \mathrm{b}}$ \\
\hline SP & Glycine & $1.41 \pm 0.15^{\mathrm{a}, \mathrm{b}}$ & $1.2 \pm 0.1^{\mathrm{a}, \mathrm{b}}$ \\
\hline SP & Histidine & $0.69 \pm 0.15^{\mathrm{e}, \mathrm{f}}$ & $0.7 \pm 0.1^{\mathrm{e}, \mathrm{f}}$ \\
\hline SP & Aspartic acid & $1.52 \pm 0.08^{\mathrm{a}, \mathrm{b}}$ & $1.2 \pm 0.1^{\mathrm{a}, \mathrm{b}}$ \\
\hline SP & Glutamic acid & $1.50 \pm 0.15^{\mathrm{a}, \mathrm{b}}$ & $1.3 \pm 0.1^{\mathrm{a}}$ \\
\hline SP & Arginine & $1.37 \pm 0.15^{\mathrm{a}, \mathrm{b}}$ & $1.1 \pm 0.1^{\mathrm{a}, \mathrm{b}, \mathrm{c}}$ \\
\hline SP & Lysine & $0.86 \pm 0.28^{\mathrm{d}, \mathrm{e}}$ & $0.8 \pm 0.2^{\mathrm{d}, \mathrm{e}}$ \\
\hline SP & Tyrosine & $0.65 \pm 0.12^{e, f, g}$ & $0.6 \pm 0.1^{\mathrm{e}, \mathrm{f}, \mathrm{g}}$ \\
\hline SP & Leucine & $0.51 \pm 0.15^{\mathrm{f,g}}$ & $0.6 \pm 0.1^{\mathrm{f}, \mathrm{g}}$ \\
\hline SP & Stearic acid & $0.34 \pm 0.22^{\mathrm{g}}$ & $0.4 \pm 0.2^{\mathrm{g}}$ \\
\hline SP & Palmitic acid & $1.31 \pm 0.17^{\mathrm{a}, \mathrm{b}, \mathrm{c}}$ & $1.1 \pm 0.1^{\mathrm{a}, \mathrm{b}, \mathrm{c}}$ \\
\hline SP & Oleic acid & $1.08 \pm 0.21^{\mathrm{c}, \mathrm{d}}$ & $1.0 \pm 0.1^{\mathrm{c}, \mathrm{d}}$ \\
\hline SP & Choline chloride & $1.30 \pm 0.11^{\mathrm{b}, \mathrm{c}}$ & $1.0 \pm 0.1^{\mathrm{b}, \mathrm{c}}$ \\
\hline SP & Acetic acid & $1.35 \pm 0.22^{\mathrm{a}, \mathrm{b}}$ & $1.1 \pm 0.1^{\mathrm{a}, \mathrm{b}, \mathrm{c}}$ \\
\hline SP & Butyric acid & $1.59 \pm 0.22^{\mathrm{a}}$ & $1.3 \pm 0.2^{\mathrm{a}}$ \\
\hline SP & Adipic acid & $1.52 \pm 0.19^{\mathrm{a}, \mathrm{b}}$ & $1.2 \pm 0.1^{\mathrm{a}, \mathrm{b}}$ \\
\hline
\end{tabular}

${ }^{*}$ Tests conducted on bonded maple wood composites strips 0.5 in. x 3.5 in. with a glued 0.5 in. x 1.0 in overlap between two strips.

${ }^{* *} \mathrm{n}=10$ for each treatment. Data in CSP and SP groups separately subjected to statistical analysis. Data in each column with the same superscript letter indicates that the treatments are not significantly different at $\mathrm{p}=0.05$. 
Table 4. Tensile strength and elongation at break for cottonseed protein isolate with selected additives at different concentrations ${ }^{*}$

\begin{tabular}{|c|c|c|}
\hline Additive, concentration & $\begin{array}{l}\text { Tensile strength } \\
\text { (MPa) }\end{array}$ & $\begin{array}{c}\text { Elongation at break } \\
(\%)\end{array}$ \\
\hline None & $2.51 \pm 0.21^{\mathrm{j}, \mathrm{k}}$ & $1.9 \pm 0.2^{\mathrm{e}, \mathrm{f}}$ \\
\hline Aspartic acid, $30 \mathrm{mM}$ & $3.30 \pm 0.39^{\mathrm{c}, \mathrm{d}}$ & $2.4 \pm 0.2^{b, c}$ \\
\hline Aspartic acid, $60 \mathrm{mM}$ & $3.50 \pm 0.30^{\mathrm{b}, \mathrm{c}}$ & $2.5 \pm 0.3^{\mathrm{a}, \mathrm{b}}$ \\
\hline Aspartic acid, $100 \mathrm{mM}$ & $3.74 \pm 0.40^{\mathrm{a}}$ & $2.7 \pm 0.2^{\mathrm{a}}$ \\
\hline Aspartic acid, $500 \mathrm{mM}$ & $3.46 \pm 0.30^{b, c}$ & $2.6 \pm 0.2^{\mathrm{a}, \mathrm{b}}$ \\
\hline Aspartic acid, $750 \mathrm{mM}$ & $2.69 \pm 0.23^{g, h, i, j}$ & $2.0 \pm 0.2^{\mathrm{e}, \mathrm{f}}$ \\
\hline Aspartic acid, $1000 \mathrm{mM}$ & $2.89 \pm 0.18^{\mathrm{f}, \mathrm{g}}$ & $2.1 \pm 0.1^{\mathrm{c}, \mathrm{d}, \mathrm{e}}$ \\
\hline Glutamic acid, $30 \mathrm{mM}$ & $2.92 \pm 0.19^{\mathrm{e}, \mathrm{f}}$ & $2.2 \pm 0.1^{\mathrm{c}, \mathrm{d}, \mathrm{e}}$ \\
\hline Glutamic acid, $60 \mathrm{mM}$ & $2.87 \pm 0.25^{\mathrm{f}, \mathrm{g}, \mathrm{h}}$ & $2.2 \pm 0.2^{\mathrm{c}, \mathrm{d}, \mathrm{e}}$ \\
\hline Glutamic acid, $100 \mathrm{mM}$ & $3.19 \pm 0.32^{\mathrm{d}, \mathrm{e}}$ & $2.3 \pm 0.2^{\mathrm{b}, \mathrm{c}, \mathrm{d}}$ \\
\hline Glutamic acid, $500 \mathrm{mM}$ & $3.19 \pm 0.15^{\mathrm{d}, \mathrm{e}}$ & $2.3 \pm 0.1^{\mathrm{b}, \mathrm{c}}$ \\
\hline Glutamic acid, $750 \mathrm{mM}$ & $2.94 \pm 0.36^{\mathrm{e}, \mathrm{f}}$ & $2.0 \pm 0.2^{\mathrm{d}, \mathrm{e}, \mathrm{f}}$ \\
\hline Glutamic acid, $1000 \mathrm{mM}$ & $2.57 \pm 0.28^{\mathrm{i}, \mathrm{j}}$ & $1.8 \pm 0.2^{\mathrm{f}}$ \\
\hline Arginine, $60 \mathrm{mM}$ & $2.81 \pm 0.30^{\mathrm{f}, \mathrm{g}, \mathrm{h}, \mathrm{i}}$ & $2.1 \pm 0.2^{\mathrm{c}, \mathrm{d}, \mathrm{e}}$ \\
\hline Arginine $100 \mathrm{mM}$ & $2.81 \pm 0.25^{\mathrm{f}, \mathrm{g}, \mathrm{h}, \mathrm{i}}$ & $2.0 \pm 0.1^{\mathrm{d}, \mathrm{e}, \mathrm{f}}$ \\
\hline Arginine, $500 \mathrm{mM}$ & $2.95 \pm 0.37^{\mathrm{e}, \mathrm{f}}$ & $2.1 \pm 0.2^{\mathrm{c}, \mathrm{d}, \mathrm{e}, \mathrm{f}}$ \\
\hline Arginine, $750 \mathrm{mM}$ & $2.59 \pm 0.32^{\mathrm{i}, \mathrm{j}}$ & $1.9 \pm 0.2^{\mathrm{e}, \mathrm{f}}$ \\
\hline Arginine, $1000 \mathrm{mM}$ & $2.70 \pm 0.25^{\mathrm{g}, \mathrm{h}, \mathrm{i}, \mathrm{j}}$ & $2.0 \pm 0.2^{\mathrm{e}, \mathrm{f}}$ \\
\hline Choline $\mathrm{Cl}, 100 \mathrm{mM}$ & $2.62 \pm 0.32^{\mathrm{h}, \mathrm{i}, \mathrm{j}}$ & $1.9 \pm 0.2^{\mathrm{d}, \mathrm{e}, \mathrm{f}}$ \\
\hline Choline $\mathrm{Cl}, 500 \mathrm{mM}$ & $3.02 \pm 0.54^{\mathrm{e}, \mathrm{f}}$ & $2.1 \pm 0.3^{\mathrm{c}, \mathrm{d}, \mathrm{e}}$ \\
\hline Choline Cl, $1000 \mathrm{mM}$ & $2.65 \pm 0.26^{\mathrm{g}, \mathrm{h}, \mathrm{i}, \mathrm{j}}$ & $1.9 \pm 0.2^{\mathrm{d}, \mathrm{e}, \mathrm{f}}$ \\
\hline Choline Cl, $1500 \mathrm{mM}$ & $2.40 \pm 0.23^{\mathrm{j}, \mathrm{k}}$ & $1.7 \pm 0.1^{\mathrm{f}}$ \\
\hline Butyric acid, $50 \mathrm{mM}$ & $2.84 \pm 0.22^{\mathrm{f}, \mathrm{g}, \mathrm{h}}$ & $2.0 \pm 0.1^{\mathrm{d}, \mathrm{e}, \mathrm{f}}$ \\
\hline Butyric acid, $100 \mathrm{mM}$ & $3.48 \pm 0.22^{b, c}$ & $2.5 \pm 0.1^{\mathrm{b}}$ \\
\hline Butyric acid, $500 \mathrm{mM}$ & $2.91 \pm 0.17^{\mathrm{f}}$ & $2.1 \pm 0.1^{\mathrm{c}, \mathrm{d}, \mathrm{e}}$ \\
\hline Butyric acid, $1000 \mathrm{mM}$ & $2.44 \pm 0.15^{\mathrm{j}, \mathrm{k}}$ & $1.8 \pm 0.1^{\mathrm{e}, \mathrm{f}}$ \\
\hline Butyric acid, $1500 \mathrm{mM}$ & $2.26 \pm 0.26^{\mathrm{k}}$ & $1.7 \pm 0.2^{\mathrm{f}}$ \\
\hline Adipic acid, $50 \mathrm{mM}$ & $3.31 \pm 0.25^{\mathrm{c}, \mathrm{d}}$ & $2.3 \pm 0.2^{b, c, d}$ \\
\hline Adipic acid, $100 \mathrm{mM}$ & $3.43 \pm 0.25^{\mathrm{b}, \mathrm{c}}$ & $2.5 \pm 0.1^{\mathrm{b}}$ \\
\hline Adipic acid, $500 \mathrm{mM}$ & $3.61 \pm 0.23^{\mathrm{a}, \mathrm{b}}$ & $2.5 \pm 0.2^{b}$ \\
\hline Adipic acid, $1000 \mathrm{mM}$ & $3.34 \pm 0.34^{\mathrm{c}, \mathrm{d}}$ & $2.3 \pm 0.3^{\mathrm{b}, \mathrm{c}}$ \\
\hline Adipic acid, $1500 \mathrm{mM}$ & $1.68 \pm 0.39^{1}$ & $1.3 \pm 0.2^{\mathrm{g}}$ \\
\hline
\end{tabular}

${ }^{*}$ Tests conducted on bonded maple wood composites strips 0.5 in. x 3.5 in. with a glued 0.5 in. x 1.0 in overlap between two strips.

${ }^{* *} \mathrm{n}=10$ for each treatment. Data in each column with the same superscript letter indicates that the treatments are not significantly different at $\mathrm{p}=0.05$. 
Table 5. Tensile strength and elongation at break for soy protein isolate with selected additives at different concentrations ${ }^{*}$

\begin{tabular}{|c|c|c|}
\hline Additive, concentration & $\begin{array}{c}\text { Tensile strength }^{* *} \\
(\mathrm{MPa})\end{array}$ & $\begin{array}{c}\text { Elongation at break }^{* *} \\
(\%)\end{array}$ \\
\hline None & $1.50 \pm 0.15^{\mathrm{b}, \mathrm{c}, \mathrm{d}}$ & $1.2 \pm 0.1^{\mathrm{a}, \mathrm{b}, \mathrm{c}}$ \\
\hline Aspartic acid, $30 \mathrm{mM}$ & $1.53 \pm 0.18^{\mathrm{b}, \mathrm{c}, \mathrm{d}}$ & $1.3 \pm 0.3^{\mathrm{a}}$ \\
\hline Aspartic acid, $60 \mathrm{mM}$ & $1.50 \pm 0.11^{\mathrm{b}, \mathrm{c}, \mathrm{d}}$ & $1.2 \pm 0.1^{\mathrm{a}, \mathrm{b}}$ \\
\hline Aspartic acid, $100 \mathrm{mM}$ & $1.42 \pm 0.12^{\mathrm{c}, \mathrm{d}, \mathrm{e}}$ & $1.2 \pm 0.1^{\mathrm{b}, \mathrm{c}}$ \\
\hline Aspartic acid, $500 \mathrm{mM}$ & $1.31 \pm 0.22^{\mathrm{e}, \mathrm{f}, \mathrm{g}}$ & $1.1 \pm 0.1^{\mathrm{b}, \mathrm{c}, \mathrm{d}}$ \\
\hline Aspartic acid, $750 \mathrm{mM}$ & $1.19 \pm 0.32^{\mathrm{g}, \mathrm{h}, \mathrm{i}}$ & $1.0 \pm 0.2^{\mathrm{c}, \mathrm{d}, \mathrm{e}}$ \\
\hline Aspartic acid, $1000 \mathrm{mM}$ & $1.23 \pm 0.26^{\mathrm{fg}, \mathrm{h} h}$ & $1.0 \pm 0.2^{\mathrm{c}, \mathrm{d}, \mathrm{e}}$ \\
\hline Glutamic acid, $30 \mathrm{mM}$ & $1.59 \pm 0.11^{\mathrm{a}, \mathrm{b}, \mathrm{c}}$ & $1.3 \pm 0.1^{\mathrm{a}}$ \\
\hline Glutamic acid, $60 \mathrm{mM}$ & $1.53 \pm 0.18^{\mathrm{b}, \mathrm{c}, \mathrm{d}}$ & $1.3 \pm 0.1^{\mathrm{a}}$ \\
\hline Glutamic acid, $100 \mathrm{mM}$ & $1.45 \pm 0.11^{\mathrm{c}, \mathrm{d}, \mathrm{e}}$ & $1.2 \pm 0.1^{\mathrm{a}, \mathrm{b}, \mathrm{c}}$ \\
\hline Glutamic acid, $500 \mathrm{mM}$ & $1.50 \pm 0.17^{\mathrm{b}, \mathrm{c}, \mathrm{d}}$ & $1.3 \pm 0.1^{\mathrm{a}}$ \\
\hline Glutamic acid, $750 \mathrm{mM}$ & $1.64 \pm 0.15^{\mathrm{a}, \mathrm{b}}$ & $1.2 \pm 0.1^{\mathrm{a}, \mathrm{b}}$ \\
\hline Glutamic acid, $1000 \mathrm{mM}$ & $1.54 \pm 0.12^{\mathrm{a}, \mathrm{b}, \mathrm{c}, \mathrm{d}}$ & $1.2 \pm 0.1^{\mathrm{b}, \mathrm{c}}$ \\
\hline Arginine, $60 \mathrm{mM}$ & $1.45 \pm 0.17^{\mathrm{c}, \mathrm{d}, \mathrm{e}}$ & $1.1 \pm 0.1^{\mathrm{b}, \mathrm{c}, \mathrm{d}}$ \\
\hline Arginine, $100 \mathrm{mM}$ & $1.49 \pm 0.17^{\mathrm{b}, \mathrm{c}, \mathrm{d}}$ & $1.2 \pm 0.1^{\mathrm{b}, \mathrm{c}}$ \\
\hline Arginine, $500 \mathrm{mM}$ & $1.37 \pm 0.15^{\mathrm{e}, \mathrm{f}, \mathrm{g}}$ & $1.1 \pm 0.1^{\mathrm{b}, \mathrm{c}, \mathrm{d}}$ \\
\hline Arginine, $750 \mathrm{mM}$ & $1.05 \pm 0.15^{\mathrm{i}, \mathrm{j}}$ & $1.0 \pm 0.2^{\mathrm{d}, \mathrm{e}}$ \\
\hline Arginine, $1000 \mathrm{mM}$ & $0.88 \pm 0.14^{\mathrm{k}}$ & $0.9 \pm 0.1^{\mathrm{e}, \mathrm{f}}$ \\
\hline Choline Cl, $100 \mathrm{mM}$ & $1.32 \pm 0.17^{\mathrm{e}, \mathrm{f}, \mathrm{g}}$ & $1.1 \pm 0.1^{\mathrm{b}, \mathrm{c}, \mathrm{d}, \mathrm{e}}$ \\
\hline Choline $\mathrm{Cl}, 500 \mathrm{mM}$ & $1.30 \pm 0.11^{\mathrm{f}, \mathrm{g}, \mathrm{h}}$ & $1.0 \pm 0.1^{\mathrm{c}, \mathrm{d}, \mathrm{e}}$ \\
\hline Choline Cl, $1000 \mathrm{mM}$ & $0.94 \pm 0.11^{\mathrm{j}, \mathrm{k}}$ & $0.8 \pm 0.1^{\mathrm{f}}$ \\
\hline Choline Cl, $1500 \mathrm{mM}$ & $0.95 \pm 0.12^{\mathrm{j}, \mathrm{k}}$ & $0.9 \pm 0.1^{\mathrm{e}, \mathrm{f}}$ \\
\hline Butyric acid, $50 \mathrm{mM}$ & $1.28 \pm 0.32^{\mathrm{fg}, \mathrm{h}}$ & $1.1 \pm 0.2^{\mathrm{b}, \mathrm{c}, \mathrm{d}, \mathrm{e}}$ \\
\hline Butyric acid, $100 \mathrm{mM}$ & $1.39 \pm 0.17^{\mathrm{de}, \mathrm{f}}$ & $1.1 \pm 0.1^{\mathrm{b}, \mathrm{c}, \mathrm{d}}$ \\
\hline Butyric acid, $500 \mathrm{mM}$ & $1.59 \pm 0.22^{\mathrm{a}, \mathrm{b}, \mathrm{c}}$ & $1.3 \pm 0.2^{\mathrm{a}, \mathrm{b}, \mathrm{c}}$ \\
\hline Butyric acid, $1000 \mathrm{mM}$ & $1.35 \pm 0.15^{\mathrm{e}, \mathrm{f}, \mathrm{g}}$ & $1.1 \pm 0.1^{\mathrm{b}, \mathrm{c}, \mathrm{d}}$ \\
\hline Butyric acid, $1500 \mathrm{mM}$ & $1.70 \pm 0.26^{\mathrm{a}}$ & $1.3 \pm 0.2^{\mathrm{a}}$ \\
\hline Adipic acid, $50 \mathrm{mM}$ & $1.56 \pm 0.14^{\mathrm{b}, \mathrm{c}}$ & $1.2 \pm 0.1^{\mathrm{a}, \mathrm{b}}$ \\
\hline Adipic acid, $100 \mathrm{mM}$ & $1.61 \pm 0.18^{a . b}$ & $1.2 \pm 0.1^{\mathrm{a}, \mathrm{b}}$ \\
\hline Adipic acid, $500 \mathrm{mM}$ & $1.52 \pm 0.19^{\mathrm{b}, \mathrm{c}, \mathrm{d}}$ & $1.2 \pm 0.1^{\mathrm{a}, \mathrm{b}, \mathrm{c}}$ \\
\hline Adipic acid, $1000 \mathrm{mM}$ & $1.42 \pm 0.28^{\mathrm{c}, \mathrm{d}, \mathrm{e}}$ & $1.1 \pm 0.2^{\mathrm{b}, \mathrm{c}, \mathrm{d}}$ \\
\hline Adipic acid, $1500 \mathrm{mM}$ & $1.16 \pm 0.21^{\mathrm{h}, \mathrm{i}}$ & $1.0 \pm 0.1^{\mathrm{d}, \mathrm{e}}$ \\
\hline
\end{tabular}

${ }^{*}$ Tests conducted on bonded maple wood composites strips 0.5 in. x 3.5 in. with a glued $0.5 \mathrm{in}$. $x 1.0$ in overlap between two strips.

${ }^{* *} \mathrm{n}=10$ for each treatment. Data in each column with the same superscript letter indicates that the treatments are not significantly different at $\mathrm{p}=0.05$. 
Table 6. Hot water resistance properties for cottonseed protein (CSP) and soy protein (SP) isolates with selective modifiers at $0.5 \mathrm{M}$ concentration ${ }^{*}$

\begin{tabular}{llcccc}
\hline Protein & \multicolumn{1}{c}{ Modifier } & \#obs. & $\begin{array}{c}\text { tensile } \\
\text { strength }^{* * *} \\
(\mathrm{MPa})\end{array}$ & $\begin{array}{c}\text { Elongation at } \\
\text { break }^{* * * *} \\
(\%)\end{array}$ & $\begin{array}{c}\text { Number of wood } \\
\text { breaks }^{* * * * *}\end{array}$ \\
\hline CSP & None & 10 & $3.11 \pm 0.34^{\mathrm{a}, \mathrm{b}}$ & $5.3 \pm 0.6^{\mathrm{a}}$ & 6 \\
CSP & Aspartic acid & 10 & $2.94 \pm 0.23^{\mathrm{a}, \mathrm{b}}$ & $4.7 \pm 1.0^{\mathrm{a}, \mathrm{b}, \mathrm{c}}$ & 9 \\
CSP & Glutamic acid & 10 & $2.82 \pm 0.39^{\mathrm{b}}$ & $3.9 \pm 1.0^{\mathrm{c}}$ & 9 \\
CSP & Arginine & 10 & $2.88 \pm 0.23^{\mathrm{a}, \mathrm{b}}$ & $4.1 \pm 0.7^{\mathrm{b}, \mathrm{c}}$ & 9 \\
CSP & Butyric acid & 10 & $3.11 \pm 0.28^{\mathrm{a}, \mathrm{b}}$ & $4.9 \pm 1.0^{\mathrm{a}, \mathrm{b}}$ & 7 \\
CSP & Adipic acid & 10 & $3.07 \pm 0.37^{\mathrm{a}, \mathrm{b}}$ & $5.1 \pm 0.3^{\mathrm{a}, \mathrm{b}}$ & 10 \\
CSP & Acetic acid & 10 & $3.26 \pm 0.18^{\mathrm{a}}$ & $4.6 \pm 0.4^{\mathrm{a}, \mathrm{b}, \mathrm{c}}$ & 10 \\
& & & & & \\
SP & None & 10 & $0.61 \pm 0.29^{\mathrm{c}}$ & $2.8 \pm 0.7^{\mathrm{d}}$ & 0 \\
SP & Aspartic acid & 2 & $0.11 \pm 0.01^{\mathrm{d}}$ & $2.3 \pm 0.3^{\mathrm{d}, \mathrm{e}}$ & 0 \\
SP & Glutamic acid & 3 & $0.17 \pm 0.05^{\mathrm{d}}$ & $1.9 \pm 0.2^{\mathrm{d}, \mathrm{e}}$ & 0 \\
SP & Arginine & 0 & & & \\
SP & Butyric acid & 10 & $0.47 \pm 0.21^{\mathrm{c}}$ & $2.4 \pm 0.5^{\mathrm{d}, \mathrm{e}}$ & 0 \\
SP & Adipic acid & 7 & $0.14 \pm 0.08^{\mathrm{d}}$ & $1.7 \pm 0.3^{\mathrm{e}}$ & 0 \\
SP & Acetic acid & 9 & $0.46 \pm 0.21^{\mathrm{c}}$ & $2.2 \pm 0.3^{\mathrm{d}, \mathrm{e}}$ & 0 \\
\hline
\end{tabular}

\footnotetext{
${ }^{*}$ Testing conducted on bonded wood composite strips 1.0 in. $x 3.5$ in. with a 1.0 in. $x 1.0$ in. overlap between two strips.

** Number of wood composites that remained attached after hot water treatment. (Total number of wood composites $=10$.) Only composites where wood strips stayed attached were tested for tensile strength and elongation at break.

${ }^{* * *}$ Data in each column with the same superscript letter indicates that the treatments are not significantly different at $\mathrm{p}=0.05$.

${ }^{* * * *}$ Number of veneer strips that fractured during testing at places other than the adhesive joint. In these cases the joint was stronger than the wood veneer itself.
} 